Chapman University

Chapman University Digital Commons

Business Faculty Articles and Research

Business

$12-7-2013$

\title{
Recognizing and Resolving Social Dilemmas in Supply Chain Public-Private Partnerships
}

\author{
Matthew McCarter \\ University of Texas - San Antonio, mccarter@chapman.edu \\ Darcy Fudge Kamal \\ Chapman University, kamal@chapman.edu
}

Follow this and additional works at: https://digitalcommons.chapman.edu/business_articles

\section{Recommended Citation}

McCarter, M. W. and Fudge Kamal, D. (2013), Recognizing and Resolving Social Dilemmas in Supply Chain Public-Private Partnerships. JOURNAL OF BUSINESS LOGISTICS, 34: 360-372. doi: 10.1111/jbl.12033

This Article is brought to you for free and open access by the Business at Chapman University Digital Commons. It has been accepted for inclusion in Business Faculty Articles and Research by an authorized administrator of Chapman University Digital Commons. For more information, please contact laughtin@chapman.edu. 


\section{Recognizing and Resolving Social Dilemmas in Supply Chain Public-Private Partnerships}

\section{Comments}

This is the accepted version of the following article:

McCarter, M. W. and Fudge Kamal, D. (2013), Recognizing and Resolving Social Dilemmas in Supply Chain Public-Private Partnerships. JOURNAL OF BUSINESS LOGISTICS 34, 360-372.

which has been published in final form at DOI: 10.1111/jbl.12033

\section{Copyright}

Council of Supply Chain Management Professionals 


\title{
RECOGNIZING AND RESOLVING SOCIAL DILEMMAS \\ IN SUPPLY CHAIN PUBLIC-PRIVATE PARTNERSHIPS
}

\author{
Matthew W. McCarter \\ College of Business \\ University of Texas at San Antonio \\ San Antonio, TX 78249 \\ matthew.mccarter@utsa.edu \\ Darcy Fudge Kamal \\ Argyros School of Business \& Economics \\ Chapman University \\ Orange, CA 92866
}

****Pre-copy Edited Version***

Forthcoming in Journal of Business Logistics

Authors' note: This paper benefited from the comments of Wesley Randall, Colin Wooldridge, and three anonymous reviewers. Portions of this paper were presented at the 2013 Annual Academy of Management Conference in Orlando, Florida. Please direct all correspondence to the first author. 


\begin{abstract}
The public-private partnership is a popular strategy for creating global sustainable value. However, many public-private partnerships struggle to realize their value-added potential. Why do some public-private partnerships succeed while others fail, and how may those struggling succeed? Combining supply-chain integration and social dilemma perspectives into the conversation of public-private partnerships, we examine the dynamics and psychology of cooperation necessary for public-private partnership success. Addressing the first part of our research question, we recognize three social dilemmas that can manifest while managing publicprivate partnership supply chains: a give-some dilemma, a take-some dilemma, and a give-ortake-some dilemma. To address the second part of our research question, we present a taxonomy of strategies resolving these public-private partnership social dilemmas through the enhancement of trust, self-efficacy, and/or social responsibility. We discuss implications for public-private partnerships, supply-chain, and social dilemma literatures.
\end{abstract}

Keywords: cooperation, give-some dilemma, take-some dilemma, public-private partnership, social dilemma, supply-chain integration 


\section{INTRODUCTION}

The public-private partnership (PPP) is a popular strategy for achieving collective action in cities, states, and nations (Skelcher, 2005). Further, PPPs are capturing interest of supplychain management and public-policy scholars (Fawcett, Waller, \& Bowersox, 2011; Hodge \& Greve, 2007; Yescombe, 2007). One reason for a PPP's appeal involves enhancing social welfare (Linder, 1999) through “global sustainable value creation” (Mahoney, McGahan, \& Pitelis, 2009) that neither public nor private entities could achieve on their own. The second appealing quality is that the risks and rewards of PPPs are shared among partners (Kovács \& Tatham, 2009; Ruben, Boselie, \& Lu, 2007).

Despite their attractiveness, many PPPs struggle to create projected value (Hodge, 2004). Because PPPs are to enhance social welfare, their failure often brings heavy costs - not only on exchange partners (e.g., damaged relationship) but on third-party stakeholders (e.g., tax payers and community members) who rely on the PPP (Muraskin, 1998). The struggle of PPPs leads some to comment that PPPs “seem to have the potential to address society's most complex problems [but] often appear to produce little of value” (Koschmann, Kuhn, \& Pfarrer, 2012, p. 332). We address the two-part research question "Why do some public-private partnerships succeed while others fail, and how may those struggling succeed?”

The psychology and dynamics of cooperation may provide a foundation to answer our research question. Weihe (2010) observes that, while considerable research on PPP formation exists, little research addresses how cooperation is generated and sustained after PPPs are formed. Fawcett et al. (2011) suggest that, create value, PPPs must not only effectively integrate supply-chain resources to create value but cooperatively share risks and rewards. 
We draw from two literatures to understand cooperation in PPPs: supply-chain integration and social dilemmas. We submit that sustaining cooperation in integrated PPP supply chains creates three social dilemmas: the give-some dilemma, the take-some dilemma, and the give-or-take-some dilemma (Dawes, 1980; McCarter, Budescu, \& Scheffran, 2011). We offer a taxonomy of strategies for navigating these social dilemmas through enhancing trust, self-efficacy, and social responsibility among supply-chain partners.

Our article makes three main contributions. First, our research answers Weihe's (2010) call for examining the micro-foundations to sustained cooperation in PPPs. Second, the PPP context necessitates the introduction of take-some and give-or-take-some dilemmas complementing well-known give-some dilemmas - into the supply-chain literature. Introducing these two social dilemmas opens discussion about collective-action problems that occur after supply-chain partners successfully pool resources. Third, our taxonomy uses governance value analysis (Ghosh \& John, 1999) to provide specific solutions to solve social dilemmas for PPP supply chains.

The remainder of this paper is divided into four sections. Section one reviews the supplychain integration literature germane to PPPs. Section two recognizes that integration of PPP supply chains is a social dilemma, and discusses three social dilemmas in PPPs. Section three deduces a taxonomy of solutions resolving PPP social dilemmas. Section four concludes with implications of our taxonomy for PPP, supply-chain integration, and social dilemma literatures.

\section{PUBLIC-PRIVATE PARTNERSHIPS AND SUPPLY CHAIN INTEGRATION}

In our literature review we followed the steps outlined by Creswell (2008, p. 29-30). We identified initial keywords public-private partnership and cross-sector partnership and searched EBSCO and Google Scholar databases. We began with influential papers and, using a "snowball 
technique” (Tikao, Higgins, Phillips, \& Cowan, 2009), examined these key papers’ reference sections for additional papers germane to our research question. The snowball process continued until we saturated the major articles relevant to our research question. We mapped these articles to our research questions to determine their relevance and themes.

In mapping the articles, two themes emerged. First, the majority of research focuses on the formation of PPPs - their structures and policy designs. Second, there is a dearth of research on sustaining cooperation after PPP formation (Weihe, 2010). Fawcett et al.’s (2011) discussion on PPPs suggests that the supply-chain integration and social dilemma literatures hold promise in understanding the dynamics of cooperation in PPPs. Based on these observations from the first literature search, we then conducted a second search for keywords including supply-chain integration (collaboration and management), governance value analysis, social dilemma, givesome dilemma, take-some dilemma, and give-or-take-some dilemma. The remainder of this paper merges the supply-chain integration and social dilemma literatures to better understand PPP success.

\section{Public-Private Partnerships}

A public-private partnership (PPP) is a form of “cross-sector partnership" - a "social organization” composed of public and private entities attempting to create global sustainable value (Koschmann et al., 2012, p. 332). A PPP's value is (in)direct and sustainable because stakeholders reap benefits both within and outside the partnership - and PPPs improve the living environment for individuals, communities, and nations (Mahoney et al., 2009).

While there are many PPP forms, we focus on “strategic partnerships” (Skelcher, 2005), a PPP that seeks a collaborative advantage (Vangen \& Huxham, 2003) through "permeable organizing practices” (Grimshaw, Vincent, \& Willmott, 2002, p. 482). The sharing of risks and 
rewards is a primary benefit and challenge for such PPPs (Heald \& Georgiou, 2010; Ibrahim, Price, \& Dainty, 2006). The next subsections use supply-chain integration and social dilemma literatures to understand the dynamics of sharing risks and rewards in PPPs.

\section{Supply-Chain Integration in the Conversation of Public-Private Partnerships}

Most PPPs are part of a supply chain or "a set of three or more entities (organizations or individuals) directly involved in the upstream and downstream flows of products, services, finances, and/or information from a source to a customer” (Mentzer et al., 2001, p. 4). Supplychain integration is the key to value creation (Cao \& Zhang, 2011) and is "the extent to which a firm is strategically interconnected and aligned with its supply-chain partners” (Schoenherr \& Swink, 2012, p. 99). The first descriptor, interconnected, refers to sharing risks and rewards among supply-chain members (Cooper, Lambert, \& Pagh, 1997). The second descriptor, align, connotes that partners cooperatively share risks and rewards, sacrificing the firm's interests in favor of maximizing the supply-chain's interests (McCarter \& Northcraft, 2007).

There are at least two insights gained by applying supply-chain integration to PPP governance. First, as the PPP's supply-chain integration increases, the PPP's performance increases (Frohlich \& Westbrook, 2001). Schoenherr and Swink’s (2012) supply-chain integration definition suggests that deciding to integrate processes, information, and other resources is only the beginning. For Schoenherr and Swink, cooperatively sharing risks and rewards is necessary to make supply-chain integration yield anticipated benefits. Following this idea our discussion assumes PPP formation occurs within a supply chain where PPP supply chain integration is a continuing "relationship building” process (Lambert, Emmelhainz, \& Gardner, 1999). 
The degree of PPP supply-chain integration adapts to resource and governance constraints. We develop PPP supply-chain integration in using governance value analysis (Ghosh \& John, 1999). Governance value analysis describes the extent to which partners cooperatively create value depends on the governance of the relationship, inimitable resources, and strategic position of the partners (Ghosh \& John, 1999). Governance value analysis theory provides a way of understanding why PPPs tackling the same social problem may do so by integrating their

resources differently (Nickerson, Hamilton, \& Wada, 2001). To illustrate, Kovács and colleagues (2012) find that job advertisements for humanitarian logisticians vary for similar disasters based on the complexity of coordination responses. In Haiti, job advertisements were short and specific, focusing on functional logistics. In other disaster responses (e.g., Sudan and Congo), job advertisements were lengthy with a broad swath of skills. In Haiti, coordination was wellspecified with each transaction managed at arm's length. In the Congo, transactions required additional cooperation between supply chain representatives. The PPPs varying approaches to integration expose them to unique solutions that induce the social dilemma: attempting mutual cooperation when sharing risks and rewards (Fawcett, Allred, Magnan, \& Ogden, 2009).

\section{RECOGNIZING PUBLIC-PRIVATE PARTNERSHIP SOCIAL DILEMMAS}

Garrett Hardin’s (1974, p. 562) discussion about human cooperation suggests that the first step toward achieving collective action is to "create ... awareness" of the social dilemmas so “that people will be able to recognize [a social dilemma’s] many varieties, however, disguised.” Following Hardin's recommendation, we recognize that integration of a PPP's supply chain is a social dilemma (McCarter \& Northcraft, 2007). A social dilemma is "a situation in which there is a strategy that provides an [individual] with the best payoff in at least one configuration of strategy choices and that strategy has a negative impact on the interests of the other [individuals] 
involved, and the choice of that particular strategy by all [or enough individuals] results in a deficient outcome” (Liebrand, 1983, p. 124). Applying the social dilemma paradigm to PPPs, we maintain that anytime a PPP integrates its supply chain, the sharing of risks and rewards creates a temptation to enjoy the rewards while avoiding the risks (Zeng \& Chen, 2003). The tension of cooperatively sharing risks and rewards involves the allocation and distribution of shared resources (Fawcett, Magnan, \& McCarter, 2008a). In social dilemmas, effective allocation and distribution of shared resources enhances social welfare, while opportunistic behavior damages social welfare (Komorita \& Parks, 1994). The resources allocated and distributed can be tangible (e.g., money, inventory, or water) or intangible; e.g., effort, affirmation, ideas, or acceptance.

A classic social dilemma is the "Tragedy of the Commons" (Hardin, 1968). Hardin (1968) imagines a group of herdsmen sharing a pasture (the commons). As is typical of constrained resources, the commons pasture has a carrying capacity that, once surpassed, cripples the resource permanently. Each herder wants to maximize profits by increasing the size of his herd, and the profits are private to the herdsman. However, the cost of each additional animal to the commons is born by all the herdsmen. The rational behavior for each herdsman is thus to increase the size of their herd without restraint. However, if all herdsmen increase their herd size and subsequently overgraze the commons then all the herds starve. Individual rationality in the short run leads to collective ruin in the long run - thus the social dilemma.

The social dilemma research domain comports well with the PPP literature in several ways. Both literatures identify metaphor to explain the challenges inherent to collective action (Ghere, 2001; Hardin, 1974). And, each literature stream pushes for ways of navigating collective action (Jamali, 2004; Van Lange, Joireman, Parks, \& Van Dijk, 2013). 
Dawes (1980), and more recently McCarter, Budescu, and Scheffran (2011), maintain that social dilemmas can be viewed in three metaphors. The first is a give-some dilemma, the second a take-some dilemma, and the third a give-or-take-some dilemma. The adjectives preceding each dilemma describes the focal choices individuals face to further self- or collective interests.

Our use of social dilemmas and their resolution comport with the position that microbased theories enlighten us about macro-organizational phenomena such as PPP success or failure. As observed by Staw (1991, p. 807), many “organizational actions are actually [rooted in] individual behavior[s]." When scholars say that "a major player in the supply chain decides to upgrade to a new technology” (Duclos, Vokurka, \& Lummus, 2003, p. 453), these scholars suggest that the player is acting on behalf of the firm in their role as technology adopters (e.g. Zaheer, McEvily, \& Perrone, 1998). Congruent with Staw's (1991) theorizing, we use social dilemma theory to explain why individuals cooperate or defect in PPPs.

Drawing from journalistic accounts and anecdotal evidence, the remainder of this section expounds on these three social dilemmas facing real-world PPPs managing supply chain integration. Our examples illustrate the use of these three metaphors in a PPP social dilemma context. Our use of journalistic accounts and anecdotal evidence follows Ordóñez and colleagues' (2009, p. 82) position that journalistic accounts and anecdotal evidence "raise questions, focus attention and develop ideas that should be subjected to rigorous, causal analyses.”

\section{Give-Some Dilemma}

In the give-some dilemma the stakeholder can either give resources to further the collective's interest or withhold resources to further their own interests while hoping to enjoy the benefits of collective action. The giving of resources is risky to the individual but provides 
shared rewards to others (Messick \& Brewer, 1983). A typical supply-chain example of a givesome dilemma is a shared, discretionary database that provides partners with current customer trends, state policies, and other valuable pieces of information (Connolly \& Thorn, 1990). Each supply-chain partner has incentive to withhold information while hoping the other partners give information to support the database. Yet, if all partners (or enough) withhold information then they reap no benefit (Cabrera \& Cabrera, 2002).

A give-some dilemma involving iodized salt distribution PPP. Essential natural resource distribution (e.g., water, air, and salt) often require cooperation through PPPs. The maintenance of natural resources rewards stakeholders with a long-term sustainable supply as well as positive externalities (e.g., health and well-being). At the same time, each stakeholder risks having another stakeholder exploit the resource by free-riding. The fear of others free ridding results in partners' temptation to withhold their contribution of resources. Each stakeholder must give to the partnership to enjoy joint benefit.

An example of the give-some dilemma can be found in the iodized salt delivery process in India. This 1950s PPP involves the United Nations International Children's Fund (UNICEF), the Indian government, and small-medium sized businesses in each of India’s 28 states and seven territories (Salon, 2001). While iodized salt is critical to human development, estimates suggest that nearly half of Indians suffer from iodine deficiency (UNICEF, 2010). Thus eradicating iodine deficiency would improve India's labor productivity. The Indian government established the National Iodine Deficiency Disorders Control Program to discourage consumption of noniodized salt and to encourage railway cooperation in iodized salt distribution. UNICEF contributed to the PPP by building salt treatment facilities throughout India. Local businesses contributed to the PPP by reducing the production of non-iodized salt. 
Despite the PPP's efforts to eradicate consumption of non-iodized salt, the problem persists. The parties have failed to give sufficient resources to support the PPP. Small and medium sized firms resisted giving up their non-iodized salt production. The national and regional governments failed to provide regulatory enforcement and oversight by not completing a ban on non-iodized salt (Indo Asian News Service, 2011). The end result was that the salt iodization facilities fell into disrepair due to half-hearted contributions by firms and the government (Chen \& Bachrach, 2003). Currently, UNICEF's efforts include using local agricultural distributors to offset marketing, distribution, and production costs of small and medium iodized salt businesses (Gulati, 2009).

\section{Take-Some Dilemma}

Take-some dilemmas occur when a stakeholder chooses to take a portion of shared resources to further their self-interests instead of leaving those resources to benefit the collective (Messick \& Brewer, 1983). This dilemma manifests itself in two forms. First, the stakeholder can access and overuse the shared resource (Ostrom, 1990). The second occurs when a stakeholder restricts access to the shared resource, making it underused (Heller \& Eisenberg, 1998). An example of the overuse in the take-some dilemma is in green supply-chain initiatives such as water management (Zhu \& Sarkis, 2004). Farmers sharing a watershed with businesses and consumers face a choice between taking as much fresh water as possible or adopting a the practice of reduced water consumption which benefits the collective (Lubell, 2004). The excessive water consumption provides the farmer with benefits such as higher crop yields while spreading the costs of reduced water supply across the other farmers, businesses, and consumers. However, if enough engage in excess consumption of water then a water shortage occurs leaving the farmers, businesses, and consumers worse off (Bronson, 2004). 
A take-some dilemma involving credit in a geo-engineering PPP. The Stratospheric Particle Injection for Climate Engineering (SPICE) Project provides an illustration of the second take-some dilemma form. This UK PPP is composed of government, universities, and Marshall Aerospace, and investigates ways of reducing global warming effects through geo-engineering (Daily Mail, 2011). The PPP created a large balloon that sprays particles into the atmosphere with the hope of cooling down a geographic region. The success of the PPP is made possible by collaborative innovations from public and private institutions. While collaboration was initially successful, the project was indefinitely suspended in May 2012 (Cressey, 2012).

The project disruption was because individual stakeholders took inappropriate amounts of credit (Graham \& Cooper, in press). Several of the teams tried to patent processes and technologies that were arguably the result of the collaboration and not the individual team. The take-some dilemma here is in the form of exercising intellectual property rights and economic rents at the cost of the overall project (Marshall, 2012). More specifically, the more credit one team took the less credit there was for others. Further the use of regulation through patents increased the transaction costs by forcing teams to get permission to use and distribute any future profits earned from the project's innovations. The inability to determine fair governance, in this case whether it is fair to patent portions of the collaborative work, resulted in PPP "gridlock" (Heller, 2008).

\section{Give-or-Take-Some Dilemma}

The third, and least studied, social dilemma is the give-or-take-some dilemma - a combination of the give-some and take-some dilemmas (Van Lange et al., 2013). A give-or-takesome dilemma is when some individuals give while others take from a shared resource. In this dilemma social welfare suffers when too little is given, or too much taken, from shared resources 
(McCarter, Budescu, \& Scheffran, 2011). The give-or-take-some dilemma highlights social problems that are composed of several, interlinked social dilemmas, where the dilemma can happen on the giving side, the taking side, or both.

Supply-chain examples of the give-or-take-some dilemmas are humanitarian supply chains engaged in providing world food “banks” (Hardin, 1974, 1985). Hardin (1974) describes this dilemma using a humanitarian supply chain where a fortunate nation's farmers and citizens sell or give food and other provisions to local non-government organizations. These nongovernment organizations then transport these supplies to less-fortunate nations. The dilemma arises because the food given to the less-fortunate nation takes away from the fortunate nation's reserves for national emergencies. As maintained by Hardin (1974), self-interests can lead to collective ruin when we an emergency strikes any stakeholder (both the fortunate and the unfortunate) and there is increasing resource needs in the unfortunate nation over time. For instance, the fortunate nation's farmers have incentive to sell to their nation's government as much food as possible for shipping across borders. At the same time the unfortunate nation's leaders have an incentive to take as much food as possible at a discounted cost without becoming self-reliant. However, persisting in this strategy may bring harm to both groups of stakeholders (Hardin, 1985). Hardin (1974) observes that the unfortunate nations' population could continue growing without improving their food production which results in more internal demand and less internal supply. The fortunate nations supply an ever increasing amount of food by the humanitarian supply chain thus increasing the probability that the fortunate nation will face a shortage during an emergency. The cycle continues until the fortunate nations cannot meet their own needs when an emergency strikes (e.g., crop failure), let alone supply enough resources for the growing unfortunate nation's needs (Hardin, 1974). 
An example of a give-or-take-some dilemma in US horse rescue PPPs. The US horse racing industry is an example of a give-or-take-some social dilemma. Like the European PPP that runs the End of Life Vehicles Directive to deal with millions of tons of auto waste each year (European Commission, 2012), the US horseracing industry has several PPPs that specialize in "disposing" of horses at the end of their useable life. In this industry, breeders supply Thoroughbred horses (alternatively known as "bloodstock") used by horse trainers and owners. A typical horse has useable product life of five to 10 years. The horse may live for an additional 10 to 20 years with diminished marginal utility. Breeders and owners face large operating expenses maintaining horses during the later years. The upstream breeders and downstream market owners face increasing expenses maintaining these horses. In recent years PPPs have formed between the government, and industry to operate non-profit horse rescues.

The PPPs face a give-or-take-some dilemma. The "giving" portion of the dilemma is due to the fact that the breeders should give their resources (e.g. excess pasture-land) to carry the costs of their unwanted horses. Likewise, horse rescues must give their resources to evaluate and re-habilitate abandoned horses. The PPP is at risk of free-riding when breeders continue breeding their horses without giving their pasture-land which results in horse rescues carrying the cost of unwanted horses. Overwhelmed, the horse rescue facilities limit capacity, unable to take on any additional unwanted horses because of free-riding by breeders.

The "taking" portion of the dilemma is due to the fact that owners capture value by selling horses to owners competing in equestrian competition. The value of an individual horse is largely determined by proven bloodlines from equestrian competition. The breeders are less likely to identify successful bloodlines when fewer owners participate in horse sports. Without owner investment, breeders keep breeding increasingly inferior horses which require more 
resource consumption for lower value products. Like the horse breeders, horse rescues capture value by adopting unwanted horses. Owners may also place a burden on the horse rescues by returning the adopted horses as they become exhausted by sharing their resources between the rescues and their sport. Rather than cooperating to create new market segments, breeders and rescues are tempted to compete for the remaining owners while neglecting opportunities for increasingly needy horses. The take-some dilemma occurs when breeders or the horse-rescues cannot extract value from the PPP by either selling horses or adopting horses.

Left unchecked this supply chain collapses from a give-or-take-some dilemma. The pernicious cycle between breeders, owners and rescues ratchets up. Breeding firms and horse rescues declared bankruptcy due to the absence of owners investing in horses. With no remaining capacity to take on the horses, many domesticated horses were set free, illegally, on other's private property and public land (Sun Times, 2012).

\section{RESOLVING PUBLIC-PRIVATE PARTNERSHIP SOCIAL DILEMMAS}

Once we are able to recognize the three social dilemmas facing PPPs, we may turn to discussing how supply-chain integration and social dilemma literatures can help us navigate these dilemmas. Answering the call for theoretical elaboration on the mechanisms and antecedents to cooperation in PPPs (Kivleniece \& Quelin, 2012), this section presents the mechanisms for cooperation and a taxonomy of modes for encouraging cooperation in PPP social dilemmas.

\section{Psychological Mechanisms to Cooperation}

Social dilemma theory identifies three cooperation mechanisms: trust (Rockmann \& Northcraft, 2008), efficacy (Kerr, 1996), and social responsibility (De Cremer \& Van Lange, 
2001). Trust is "a psychological state comprising the intention to accept vulnerability based upon positive expectations of the intentions or behavior of another" (Rousseau, Sitkin, Burt, \& Camerer, 1998, p. 395). For cooperation to occur in social dilemmas, partners must not only want to cooperate but also expect that the other partners will cooperate (McCarter, Mahoney, \& Northcraft, 2011; Morgan \& Hunt, 1994).

Efficacy is a "conviction that one can successfully execute the behavior required to produce the outcomes” (Bandura, 1977, p. 193). Comparing trust to efficacy, trust then is a motivator about intentions to cooperate. Efficacy as a motivator is about the means to cooperate (Kerr, 1992).

Lastly, social responsibility is "the moral obligation to further the collective's interest" (van Dijk \& Wilke, 1997, p. 197). When it is clear that one's actions can impact another's wellbeing, a moral norm is activated - a perception of how one should act, and failure to follow this norm diminishes self-worth (Schwartz, 1970). The idea of norms, similar to social dilemma, suggests that as individuals focus more on how their behavior affects others, they will perceive cooperation as the right course of action (Schwartz-Shea \& Simmons, 1995).

\section{A Taxonomy of Modes to Cooperation in Public-private Partnership Social Dilemmas}

Our taxonomy combines social psychology and management approaches to navigating social dilemmas. Social psychology reviews of social dilemma solutions focuses on how the solution is executed. Management research focuses on what the solution does to increase cooperation.

The first dimension of our current taxonomy comes from social psychologists Messick and Brewer (1983) who separate social dilemma solutions by whether they are unilaterally or jointly implemented. Relating this idea to PPP social dilemmas, governance value analysis suggests that PPPs may be governed autonomously or integrative (Kivleniece \& Quelin, 2012). 
Autonomous PPPs require cooperation but feature intense private firm authority. Integrated PPPs exhibit joint authority and rights between the public and private partner. The joint-unilateral dimension describes whether the intervention is imposed unilaterally (e.g., one partner behaving autonomously) or through integration which coordinated efforts by all partners in the social dilemma.

Our second taxonomic dimension is taken from management scholars Zeng and Chen (2003), who separate social dilemma solutions into whether the intervention affects the partners' perception of the social dilemma's structure, called structural solutions, or of perceptions of each partner, called motivational solutions. Delineating between structural and motivation solutions enhances understanding of how PPPs can navigate social dilemmas because PPP supply chains may need to select either proactive or reactive solutions (Martens, Crum, \& Poist, 2011). A reactive structural solution may be socially costly while a proactive motivational solution may prove impractical due to time constraints. For example, a PPP may not excuse a member as a structural solution to scale problems because of public opinion. Likewise, a motivational response may not induce cooperation quickly enough in a humanitarian emergency.

Table 1 summarizes our taxonomy with the joint-unilateral (or the means) dimension on the $\mathrm{Y}$-axis and the structural-motivational (or the ends) dimension on the $\mathrm{X}$-axis. In addition to bridging management (Zeng \& Chen, 2003) and social psychology (Messick \& Brewer, 1983) approaches to studying social dilemmas, our taxonomy allows managers to know what strategies are at their disposal as a function of the PPP's structure and manager autonomy. For instance, Quadrant IV would stem from circumstances where PPPs have difficulty manipulating payoffs and the manager enhancing the relationship among partners lacks sufficient buy-in. The taxonomy provides the manager a vehicle to consider strategies from different quadrants and 
predict whether these other strategies would be feasible in garnering collective action. The usefulness of the taxonomy requires managers to select the appropriate quadrant for their PPP.

In the remaining portion of section three, we review each quadrant in Table 1, provide two modes of enhancing cooperation, discuss the psychological mechanisms affected by the modes, and provide examples of PPPs using these modes. The two modes in each quadrant of the taxonomy are merely samples. In the current taxonomy the mechanisms - trust, efficacy, and social responsibility - are not bound to a particular quadrant or mode. In some instances, a mode’s effect on cooperation may hinge on several mechanisms.

Insert Table 1 about here

\section{Quadrant I: Joint-Structural Solutions}

Quadrant I contains joint-structural solutions coordinated and implemented by the partners to alter how the social dilemma is perceived by those involved. Two modes of jointstructural solutions are criticality and the number of partners in the PPP.

Criticality. One reason for self-interest in PPP social dilemmas is that a partner has incentive to free-ride on the cooperative behavior of others (Smith, Woodward, Acharya, Beaglehole, \& Drager, 2004). A reason for partners' free riding is that they are substitutable (McCarter \& Northcraft, 2007), that is their input is perceived as replaceable by others, because of this a partner may opt to free ride relying on others to "pick up the slack" (McCorkle et al., 1999).

One way of discouraging free-riding is to have unique critical partner contributions (Chen, Au, \& Komorita, 1996). When each partner is critical for attaining collective action, freeriding becomes impossible (Kollock, 1998). In supply chains, criticality occurs structurally or psychologically. For instance, supply-base reduction minimization the actual number of partners 
in the supply chain which reduces coordination and monitoring costs (Sarkar \& Mohapatra, 2006; Ogden \& McCarter, 2004). Creating criticality in PPPs enhances cooperation in two ways. First, individuals experience enhanced self-efficacy because they perceive themselves as having a greater impact of achieving collective action (Chen et al., 1996). Second, individuals' trust in the partnership increases because a structure with high criticality removes the incentive to freeride (McCarter \& Northcraft, 2007).

An example of this is the Tripartite First Nations Health Plan composed of the First Nations Health Council, British Columbia Ministry of Healthy Living, and Canadian Public Affairs. Tripartite First Nations Health Plan's goal is to improve the health of children and families of aboriginal descent in Canada. To encourage cooperation, the partners of this PPP stress that each other's contribution is essential and has structured the PPP such that each partner holds a resource that cannot be substituted by another partner (First Nations Health Council, 2009).

Number of partners. Another reason for self-interest in social dilemmas is that partners become overwhelmed by the complexity of achieving collective action (Weick, 1984). A common source of complexity is the number of partners attempting collective action (Franzen, 1994). PPP scholarship recognizes the potential tradeoff of partnership size. While more partners can equate to more resources, more partners can also equate to cooperation problems (Hartwich et al., 2007).

There are several reasons why decreasing the number of partners enhances cooperation. Individuals that are part of groups small in size see themselves as more efficacious in achieving collective action (Kerr, 1989). Further, trust in each other's intentions to cooperate has more of 
an impact on small groups (Sato, 1988). Hartwich and colleagues (2007) submit that controlling the number of partners is essential for PPP success for "confidence building” among partners.

Reducing the number of PPP partners, within reason, leads to lower transaction costs and higher cooperation (Olson, 1965). For example, PPPs in Kenyan vegetable supply chains faced high transaction costs because partnerships were as large as 350 partners (Narrod et al., 2009). Narrod and colleagues (2009) observed that decreasing the PPP partnership base tenfold reduced transaction costs and encourages cooperation.

\section{Quadrant II: Joint-Motivational Solutions}

Quadrant II holds the joint-motivational solutions that partners coordinate and implement to alter how they perceive one another. Two modes of encouraging cooperation through jointmotivation are perceived interdependence and beneficiary contact.

Perceived interdependence. Self-interest abounds when partners perceive their actions as completely independent. Interdependence can be established by shaping the individuals' perception of the problem (Schwartz-Shea \& Simmons, 1995). Depending on how partners frame the problem, they may place different weights on self- and collective interests (Tenbrunsel \& Northcraft, 2010). When partners view the problem differently, one partner may perceive their behavior as interdependent while others view their behavior as independent. In a study of hotel towel reuse, Goldstein et al. (2008) found that invoking a frame closer to an individual's immediate situation is more effective than general environmental appeals. Individuals are more likely to view their choices as interdependent when others perceive themselves more similar to each other.

Trust is increased when individuals view the frame as interdependent. Trust stems from individuals ability to identify with each other. For example, Goldstein et al.'s (2008) hotel towel reuse study harkens to the Christian adage "love thy neighbor as thyself". When we identify the 
others who had previously stayed in the same hotel room with ourselves we are more likely to cooperate and reuse the towels. Individuals trust through a leap of faith that the others at the hotel are indeed similar (Van de Ven \& Ring, 2006).

Such perceived interdependence could resolve the dilemma faced by horse rescues PPPs. Horse breeders may be less likely to breed beyond demand and attend to end-of-useable life care of horses if they view their breeding decisions as interdependent with horse rescues and owners. Breeding farms tend to be short-sighted during hot markets and breed several offspring despite the risk that the offspring may come of age during a cold market (Whiteley, 2010). These firms' independent decisions lead to overcapacity driving down prices. The breeding farms are worse off and must increasingly rely on the horse rescues to pick up the excess capacity of horses. Thus, the breeders need to trust each other that one breeder is not going to take advantage of others' capacity by over-breeding. By framing the problem as one of joint interdependence, the breeders are more likely to commit to managing end-of-useable life in their present breeding decisions.

Beneficiary contact. PPPs form to affect individuals, families, and communities in positive ways (Reich, 2000). In relationships, social-dilemma solutions change human behavior such that individuals, families, and communities incur social benefits rather than social burdens. Kollock (1998) suggests that individuals are not myopic in terms of self-interest, and self-interest exacerbates social dilemmas.

Social dilemmas may reach resolution by enhancing partners perceived impact on beneficiaries. A beneficiary is broadly defined as "the people and groups of people who believe their actions ... have the potential to positively affect” (Grant, 2007, p. 395). This perceived impact can be achieved by contact between the partners and beneficiary in the social dilemma. 
The PPP may be structured "to provide opportunities for [partners] to interact and communicate with the people affected by their work” (Grant, 2007, p. 398). This may be why PPPs attempting to navigate give-some dilemmas invite donors to tour program offices and meet people who receive assistance (California Polytechnic State University, 2012). Similarly, leaders in PPPs may accomplish the same thing by establishing contact between PPP partners and individual, family, and community members that affected by successful collective action (Grant, 2012). The International Organization for Migration uses such a strategy. This organization arranges for case workers to meet with individuals saved from human trafficking by the efforts of these case workers (Berman, Asheer, Miller, \& Halvorsen, 2010).

Beneficiary contact encourages cooperation by increasing efficacy, what Grant (2007) terms perceived beneficiary impact. Individuals see the impact they have on another and this feedback resolves the uncertainty about the contribution their cooperation makes (Kerr, 1992). Grant et al. (2007) found that fundraising workers' contact with beneficiaries, such as receiving appreciation letters, increased the amount of donations these workers subsequently raised, and this effect was mediated by perceived impact.

\section{Quadrant III: Unilateral-Structural Solutions}

The solutions in Quadrant III are unilateral-structural solutions implemented by individual partners to alter how the other partners perceive the social dilemma's structure. The two modes consistent with Table 1 are informal sanctions and the framing ownership.

Informal sanctions. Informal sanctions are unilateral structural mechanisms which induce cooperation in social dilemmas (Fehr \& Fischbacher, 2004). Individuals relying on informal sanctions invoke trust. Parties cooperate due to the perceived benefit that they will gain from the interaction but are wary that in a high trust/high distrust conditions an individual may 
retaliate (Lewicki, McAllister, \& Bies, 1998). Thus, “opportunities are pursued, but the risks are regularly monitored” (Rousseau et al., 1998, p. 399).

Heightened monitoring occurs when individuals use informal sanctions, such as in doctoral advisor-student relationships. For instance, doctoral students may fear that their advisors will not give them as much time and feedback, in favor of other colleagues and students, thereby omitting valuable information. In reality, the advisor may simply be managing the plethora of tasks and responsibilities at hand (Kramer, 1994). Such a heightened sensitivity causes individuals to misinterpret information related to the antecedents of trust (Kramer, 1996). Indeed, Kramer's (1994) study of student-advisor relationships found that advisors were more likely to attend to task-performance based aspects of trust, while students spent three-times more of their attention on relationship based aspects of trust. The student merely perceives a potential risk to future benefits, opts to cooperate, and continuously obsesses over such risks. Thus, informal sanctions may prime individuals to cooperate by cultivating trust and keeping the partners wary of potential retaliation even if such retaliation is indirect.

PPPs related to R\&D initiatives may experience an informal sanction when key scientific information is withheld from a scientist who fails to cooperate with their scientific community. In an R\&D alliance, a scientist who changed allegiances between the firms was outcast (de Rond, 2003). In stable communities like scientific research fields an informal sanction is effective. This is because a scientist's early research discoveries and future promotions depend on a community of scholars to promote the scientist's research stream. Thus, a PPP requiring the full cooperation of researchers face an informal sanction of lossed access to vital information and support for their research stream. 
Framing ownership. Partners involved in a social dilemma do not necessarily see the situation similarly (Tenbrunsel \& Northcraft, 2010). There is often uncertainty in situations about what rules and behaviors are appropriate (March, 1994). Because of this uncertainty, individuals perceive situations differently due to various contextual cues and different norms (Messick, 1999). Drawing from appropriateness logic, Weber et al. (2004, p. 283) submits that individuals do not only calculate the costs and benefits of cooperation in social dilemmas, but also subconsciously ask themselves "What is the normative context of this situation, and what would others expect me to do in a situation like this one?” Thus an individual's perception of socially responsibility alters by mere changes in social context, rather than the payoff structure (van Dijk \& Wilke, 1997).

Mismatched logics of appropriateness are a barrier to new geo-engineered technology that is created through the SPICE partnership (Cressey, 2012). In this PPP, partners cannot agree on who owns certain technologies. Some partners perceive the project as "theirs" and consequently perceive that they are entitled to additional rents and rights. In contrast, others perceive the project as open source and that everyone is entitled to the benefits from SPICE initiatives.

\section{Quadrant IV: Unilateral-Motivational Solutions}

Quadrant IV contains the unilateral-motivational solutions that an individual partner may use to impact how the partners view each other. The modes illustrated in this section are communication and group identity.

Communication. Communication, particularly fact to face communication, induces cooperation in social dilemmas (Dawes, McTavish, \& Shaklee, 1977). Partners gain additional information about each another and the details of the social dilemma (Kollock, 1998). 
Communication develops trust which leads to cooperation (Ostrom, 1998). Trust is created by reliable and dependable ongoing interactions (Rousseau et al., 1998). When individuals can predict the reliability of the other's actions they have a higher likelihood of cooperating with each other (Axelrod, 1984). Communication allows individuals to agree about their level of commitment to the collective and thus builds trust.

In PPPs, communicating may yield higher levels of cooperation. For instance, greater communication about the end-of-useable life problems between breeders, owners and rescues may increase their sense of commitment to managing herd levels. Breeders may plan for end-ofuseable life care, even if the long-term effects of their breeding are delayed by thirty-years. Moreover, breeders that regularly commit to conversations about population level management and end-of-useable life issues could trust each other to cooperate and manage herd levels. Indeed growing levels of industry lobbying brought the parties together who would ordinarily not meet face-to-face. Such meetings proved invaluable for additional insights into the over-population problem and subsequently increasing support. PPPs that communicate, and in particular communicate face-to-face, may have lower coordination problems (New York Thoroughbred Horseman's Association Newsletter, 2012).

Group identity. Group identity is an invaluable way of encouraging cooperation. Identity is the way that we display intentions and establish norms and build our PPP reputation (Ostrom, 1998). Norms shape the internal valuation an individual places in their actions (Ostrom, 1998). A group member might gain a positive valuation such as the "warm glow" (Andreoni, 1995) by helping another more than themselves. Alternatively, group members might incur a negative valuation by performing an act out of "duty" (Knack, 1992). Such norms foster a community which seeks to maintain and enforce a group’s identity (Coleman, 1987). 
Trust, particularly of a relational form, may elicit more of an emotional response from identification with others (Coleman, 1990). Deeply-held partner norms may be at risk of violation when actors face a social dilemma. Our reputation, built upon group identity, sets the stage for whether others can expect us act in a cooperative manner. Thus, a group’s identity and coinciding norms affect their ability to perceive each other as trustworthy and whether the group members will reciprocate (Ostrom, 1998).

A partner that encourages group identity fosters a greater sense of cooperation. This is particularly true in instances where stakeholders may have competing or conflicting beliefs regarding the group norms (Zaheer \& Fudge Kamal, 2011). UNICEF unilaterally created a shared identity with the local communities and businesses to provide iodized salt (Gulati, 2009). The local communities needed education on the health benefits of the iodized salt over naturally available salt. Efforts in aligning the project with local norms through imagery and local festivals proved invaluable. UNICEF also gained the cooperation of local companies through food cooperatives to distribute the iodized salt. The PPP for iodized salt in India claims its greatest successes due to public mobilization from a shared identity and norms of responsibility protecting the salt.

\section{DISCUSSION AND CONCLUSION}

The current theorizing responds to the seeming absence of social dilemma research (e.g. Defee, Williams, Randall, \& Thomas, 2010) in the supply chain literature. Viewing the governance of PPP supply chains as a social dilemma makes several contributions to PPP research. First, the social dilemma framework, coupled with our taxonomy, provides a psychological foundation of understanding and improving cooperation in PPPs. Weihe’s (2010) 
work on PPPs, essentially asks the question "once a PPP is formed through integration how is cooperation sustained and hindered?” Answering this question reveals a paradox of PPPs. PPPs form to address large-scale social dilemmas facing communities and nations (Kivleniece \& Quelin, 2012), and yet once PPPs form, a PPP's success is a social dilemma in and of itself. Partners are torn between cooperating and competing with each other to achieve goals that benefit themselves as well as social welfare (Das \& Teng, 2000). Our taxonomy helps navigate the cooperation-competition paradox.

Second, the majority of social dilemma research in operations management and management science focuses on give-some dilemmas (Agarwal, Croson, \& Mahoney, 2010; Celly, Spekman, \& Kamauff, 1999; Fawcett, Magnan, \& McCarter, 2008b; Gulati, Khanna, \& Nohria, 1994; Kivleniece \& Quelin, 2012; McCarter \& Northcraft, 2007; Zeng \& Chen, 2003). The emphasis on give-some dilemmas is most likely because this research focus on resource pooling as a means to create value. By introducing take-some and give-or-take-some dilemmas, we consider what comes after resource pooling. In doing so we seek to ask and answer the Hardin (1976, p. 122) question “and then what?” Hardin (1976, p. 124) observed that, when addressing social problems, "you can never do just one thing." The sustainable PPPs may become a resource that partners may desire to control. The SPICE project illustrates this dilemma. The PPP successfully pooled resources and navigated the give-some dilemma to create a new technology aimed at alleviating global warming. However, this process created a takesome dilemma. Various partners sought to take more credit and control than was perceived fair. This resulted value for no one. The resources ended up simply sitting in a warehouse. Thus, for PPPs to succeed, we submit that supply-chain integration is only the beginning of a successful cooperative PPP governance process. 
Third, our taxonomy extends the supply-chain concept of governance value analysis. Governance value analysis focuses on how alliance structures, such as those found in PPPs, form as a function of the interplay amongst partners' resources. Combining this literature with the social dilemma paradigm, we are able posit which PPP governance strategies - unilateral or joint - will be used as a function of autonomous or integrated strategic partnership. This insight holds key implications for managers seeking to govern integrated PPP supply chains by providing a starting point for what types of solutions support the partnership function of the PPP.

We use the PPP context to push our thinking about social dilemmas. Past social dilemma research makes the assumption that giving more or taking less is pro-social behavior (Dawes, 1980; Van Lange et al., 2013). However, the complexity of PPPs suggests that partners can perceive they are cooperating in a welfare-enhancing system while in actuality their “cooperative" behavior only makes social welfare worse (Hardin, 1974). While recent social dilemma scholarship observes that non-cooperative behavior can be unintentional (Tenbrunsel \& Northcraft, 2010), we extend this idea by submitting that intended cooperative behavior can actually harm the collective's welfare.

We introduce the idea of a social dilemma view to PPPs. In doing so, we provide several directions for PPPs specifically and supply chain research generally. One area for further research involves supply-chain arcs of integration (e.g. Frohlich and Westbrook, 2001). For instance, skewed arcs either upstream or downstream may be blocked from full integration. The supply chain remains skewed in its integration to compensate for a social dilemma faced at the other end of the supply chain. By considering the resources and positions of the supply-chain partners full integration, that is the outward facing arcs, may be achieved using our taxonomy. 
Another extension considers the interplay of the social dilemmas throughout a supply chain. Davis and Cobb (2010) claim that overly concentrated economic activity is linked to social inequality. Similarly, Ruester and Neumann (2009) find that transaction costs can spill over from one-transaction to the next moving upstream in a supply chain. PPPs may form as a reaction to burgeoning coordination problems due to an unresolved and pernicious social dilemma. However, the PPP integration may reflect multiple social dilemmas both upstream and downstream. Overly large public-private partnerships may be responding to various social dilemmas building throughout the supply chain. PPPs may fail to achieve desired performance benefits because the partners neglected the interplay between social dilemmas at multiple transactions.

We drew from social dilemma and supply chain management literatures to describe one reason for the success and failure of PPPs. While PPPs create value, their integration can constitute three social dilemmas. These dilemmas stem from the giving of resources, the taking of resources, or a hybrid of the two. This means that supply chain partners must maintain cooperation to enhance PPP performance. By describing this process we have established a foundation that future researchers can use to begin to address calls to understand the psychology of cooperation at the core of successful public-private partnerships. 


\section{REFERENCES}

Agarwal, R., Croson, R. T. A., \& Mahoney, J. T. 2010. The role of incentives and communication in strategic alliances: An experimental investigation. Strategic Management Journal, 31(4): 413-437.

Andreoni, J. 1995. Warm-glow versus cold-prickle: The effects of positive and negative framing on cooperation in experiments. Quarterly Journal of Economics, 110(1): 1-21.

Axelrod, R. 1984. The evolution of cooperation. New York: Basic Books.

Bandura, A. 1977. Self-efficacy: Toward a unifying theory of behavioral change. Psychological Review, 84(2): 191-215.

Berman, J., Asheer, S., Miller, R., \& Halvorsen, K. 2010. Evaluation of the International Organization for Mirgration and its efforts to combat human trafficking. Olso, Nowary: Norwegian Agency for Development Cooperation.

Bronson, C. H. 2004. The Suwannee River will become nobody's sewer, Gainsville Sun: 10A.

Cabrera, A., \& Cabrera, E. 2002. Knowledge-sharing dilemmas. Organization Studies, 23(5): 687-710.

California Polytechnic State University. 2012. Gifts in action - See the impact of your support, San Luis Obispo, CA: University Advancement. http://giving.calpoly.edu/videoarchives.html. Site accessed April 24, 2013.

Cao, M., \& Zhang, Q. 2011. Supply chain collaboration: Impact on collaborative advantage and firm performance. Journal of Operations Management, 29(3): 163-180.

Celly, K. S., Spekman, R. E., \& Kamauff, J. W. 1999. Technological uncertainty, buyer preferences and supplier assurances: an examination of Pacific Rim purchasing arrangements. Journal of International Business Studies, 30(2): 297-316.

Chen, X.-P., Au, W. T., \& Komorita, S. S. 1996. Sequential choice in a step-level public goods dilemma: The effects of criticality and uncertainty. Organizational Behavior \& Human Decision Processes, 65(1): 37-47.

Chen, X.-P., \& Bachrach, D. G. 2003. Tolerance of free-riding: The effects of defection size, defection pattern, and social orientation in a repeated public goods dilemma. Organizational Behavior \& Human Decision Processes, 90(1): 139-147.

Coleman, J. S. 1987. Norms as social capital. In G. Radnitzky, \& P. Bernholz (Eds.), Economic imperialism: The economic approach applied outside the field of economics: 133-155. New York, NY: Paragon House.

Coleman, J. S. 1990. Foundations of social theory. Cambridge, MA: Harvard University Press. 
Connolly, T., \& Thorn, B. K. 1990. Discretionary databases: Theory, data, and implications. In J. Fulk, \& C. W. Steinfield (Eds.), Organizations and communication technology: 219233. Newbury, CA: Sage.

Cooper, M. C., Lambert, D. M., \& Pagh, J. D. 1997. Supply chain management: More than a new name for logistics. International Journal of Logistics Management, 8(1): 1-14.

Cressey, D. 2012. Geoengineering experiment cancelled amid patent row, Nature: News.

Creswell, J. W. 2008. Research design: Qualitative, quantitative, and mixed methods approaches. Thousand Oaks, CA: Sage.

Daily Mail. 2011. Machines that suck up CO2 and aerosol injections into the sky: The geoengineering techniques that have got support of the public. London, UK.

Das, T. K., \& Teng, B. S. 2000. Instabilities of strategic alliances: An internal tensions perspective. Organization Science, 11(1): 77-101.

Davis, G. F., \& Cobb, J. A. 2010. Corporations and economic inequality around the world: The paradox of hierarchy. Research in Organizational Behavior, 30: 35-53.

Dawes, R. M. 1980. Social dilemmas. Annual Review of Psychology, 31: 169-193.

Dawes, R. M., McTavish, J., \& Shaklee, H. 1977. Behavior, communication, and assumptions about other people's behavior in a commons dilemma situation. Journal of Personality \& Social Psychology, 35(1): 1-11.

De Cremer, D., \& Van Lange, P. A. 2001. Why prosocials exhibit greater cooperation than proselfs: The roles of social responsibility and reciprocity. European Journal of Personality, 15(S1): S5-S18.

de Rond, G. 2003. Strategic alliances as social facts: Business, biotechnology, and intellectual history. Cambridge, UK: Cambridge University Press.

Duclos, L. K., Vokurka, R. J., \& Lummus, R. R. 2003. A conceptual model of supply chain flexibility. Industrial Management \& Data Systems, 103(6), 446-456.

European Commission. 2012. End of life vehicles. http://ec.europa.eu/environment/waste/elv_index.htm. Site accessed April 24, 2013.

Fawcett, S. E., Allred, C., Magnan, G. M., \& Ogden, J. 2009. Benchmarking the viability of SCM for entrepreneurial business model design. Benchmarking: An International Journal, 16(1): 5-29.

Fawcett, S. E., Magnan, G., \& McCarter, M. W. 2008a. A three-stage implimentation model for supply chain collaboration. Journal of Business Logistics, 29(1): 93-113. 
Fawcett, S. E., Magnan, G., \& McCarter, M. W. 2008b. Supply chain alliances and social dilemmas: Bridging the barriers that impede collaboration. International Journal of Procurement Management, 1(3): 318-342.

Fawcett, S. E., Waller, M. A., \& Bowersox, D. J. 2011. Cinderella in the C-suite: Conducting influential research to advance the logistics and supply chain disciplines. Journal of Business Logistics, 32(2): 115-121.

Fehr, E., \& Fischbacher, U. 2004. Social norms and human cooperation. Trends in Cognitive Sciences, 8(4): 185-190.

First Nations Health Council. 2009. British Columbia Tripartite First Nations health plan: Year in review 2008-2009. West Vancouver, British Columbia: First Nations Health Council.

Franzen, A. 1994. Group size effects in social dilemmas: A review of the experimental litearture and some new results from one-shot N-PD games. In U. Schulz, W. Albers, \& U. Mueller (Eds.), Social dilemmas and cooperation: 117-146. New York: New York: SpringerVerlag.

Frohlich, M. T., \& Westbrook, R. 2001. Arcs of integration: An international study of supply chain strategies. Journal of Operations Management, 19(2): 185-200.

Ghere, R. K. 2001. Probing the strategic intricacies of public-private partnership. Public Administration Review, 61(4): 441-451.

Ghosh, M., \& John, G. 1999. Governance value analysis and marketing strategy. Journal of Marketing, 63(1): 131-145.

Goldstein, N. J., Cialdini, R. B., \& Griskevicius, V. 2008. A room with a viewpoint: Using social norms to motivate environmental conservation in hotels. Journal of Consumer Research, 35(3): 472-482.

Graham, W. J., \& Cooper, W. H. in press. Taking credit. Journal of Business Ethics: 1-23.

Grant, A. M. 2007. Relational job design and the motivation to make a prosocial difference. Academy of Management Review, 32(2): 393-417.

Grant, A. M. 2012. Leading with meaning: Beneficiary contact, prosocial impact, and the performance effects of transformational leadership. Academy of Management Journal, 55(2): 458-476.

Grant, A. M., Campbell, E. M., Chen, G., Cottone, K., Lapedis, D., \& Lee, K. 2007. Impact and the art of motivation maintenance: The effects of contact with beneficiaries on persistence behavior. Organizational Behavior \& Human Decision Processes, 103(1): 53-67.

Grimshaw, D., Vincent, S., \& Willmott, H. 2002. Going privately: partnership and outsourcing in UK public services. Public Administration, 80(3): 475-502. 
Gulati, G. 2009. UNICEF catalyzes production of iodized salt: UNICEF, http://www.unicef.org/india/reallives_4809.htm. Site accessed April 24, 2013.

Gulati, R., Khanna, T., \& Nohria, N. 1994. Unilateral commitments and the importance of process in alliances. Sloan Management Review, 35(3): 61-70.

Hardin, G. 1968. The tragedy of the commons. Science, 162(3859): 1243-1248.

Hardin, G. 1974. Living on a lifeboat. BioScience, 24(10): 561-568.

Hardin, G. 1976. Carrying capacity as an ethical concept. Soundings, 59(1): 120-137.

Hardin, G. 1985. Filters against folly. New York, NY: Penguin.

Hartwich, F., Tola, J., Engler, A., Gonzalez, C., Ghezan, G., Vazquez-Alvarado, J. M. P., Silva, J. A., de Jesus Espinoza, J., \& Gottret, M. V. 2007. Building public-private partnerships for agricultural innovation. Washington D.C.: International Food Policy Research Institute.

Heald, D., \& Georgiou, G. 2010. Acconting for PPPs in a converging world. In G. A. Hodge, C. Greve, \& A. E. Boardman (Eds.), International handbook of public-private partnerships: 237-261. Cheltenham, UK: Elgar.

Heller, M. A. 2008. The gridlock economy: How too much ownership wrecks markets, stops innovation, and costs lives. New York, NY: Basic Books.

Heller, M. A., \& Eisenberg, R. S. 1998. Can patents deter innovation? The anticommons in biomedical research. Science, 280(5364): 698-701.

Hodge, G. A. 2004. The risky business of public-private partnerships. Australian Journal of Public Administration, 63(4): 37-49.

Hodge, G. A., \& Greve, C. 2007. Public-private partnerships: An international performance review. Public Administration Review, 67(3): 545-558.

Ibrahim, A., Price, A., \& Dainty, A. 2006. The analysis and allocation of risks in public private partnerships in infrastructure projects in Nigeria. Journal of Financial Management of Property and Construction, 11(3): 149-164.

Indo Asian News Service. 2011. Supreme court extends ban on non-iodized salt sale. http://in.news.yahoo.com/supreme-court-extends-ban-non-iodized-salt-sale171426422.html. Site accessed April 24, 2013.

Jamali, D. 2004. Success and failure mechanisms of public private partnerships (PPPs) in developing countries: Insights from the Lebanese context. International Journal of Public Sector Management, 17(5): 414-430. 
Kerr, N. L. 1989. Illusions of efficacy: The effects of group size on perceived efficacy in social dilemmas. Journal of Experimental Social Psychology, 25(4): 287-313.

Kerr, N. L. 1992. Efficacy as a causal and moderating variable in social dilemmas. In W. B. G. Liebrand, D. M. Messick, \& H. Wilke (Eds.), Social dilemmas: Theoretical issues and research findings: $59-80$. Oxford: Pergamon Press.

Kerr, N. L. 1996. “Does my contribution really matter?”: Efficacy in social dilemmas. In W. Stroebe, \& M. Hewstone (Eds.), European Review of Social Psychology, Vol. 7: 209240. Chichester, UK: Wiley.

Kivleniece, I., \& Quelin, B. V. 2012. Creating and capturing value in public-private ties: a private actor's perspective. Academy of Management Review, 37(2): 272-299.

Knack, S. 1992. Civic norms, social sanctions, and voter turnout. Rationality \& Society, 4(2): 133-156.

Kollock, P. 1998. Social dilemmas: The anatomy of cooperation. Annual Review of Sociology, 24: $183-214$.

Komorita, S. S., \& Parks, C. D. 1994. Social dilemmas. Madison, WI: Brown \& Benchmark.

Koschmann, M. A., Kuhn, T. R., \& Pfarrer, M. D. 2012. A communicative framework of value in cross-sector partnerships. Academy of Management Review, 37(3): 332-354.

Kovács, G., \& Tatham, P. 2009. Responding to disruptions in the supply network-from dormant to action. Journal of Business Logistics, 30(2): 215-229.

Kramer, R. M. 1994. The sinister attribution error: Paranoid cognition and collective distrust in organizations. Motivation \& Emotion, 18(2): 199-230.

Kramer, R. M. 1996. Divergent realities and convergent disappointments in the hierarchic relation: Trust and the intuitive auditor at work. In R. M. Kramer, \& T. R. Tyler (Eds.), Trust in organizations: Frontiers of theory and research: 216-245. London, UK: Sage.

Lambert, D. M., Emmelhainz, M. A., \& Gardner, J. T. 1999. Building successful logistics partnerships. Journal of Business Logistics, 20(1): 165-182.

Lewicki, R. J., McAllister, D. J., \& Bies, R. J. 1998. Trust and distrust: New relationships and realities. Academy of Management Review, 23(3): 438-458.

Liebrand, W. B. G. 1983. A classification of social dilemma games. Simulation \& Games, 14(2): 123-138.

Linder, S. H. 1999. Coming to terms with the public-private partnership. American Behavioral Scientist, 43(1): 35-51. 
Lubell, M. 2004. Collaborative watershed management: A view from the grassroots. Policy Studies Journal, 32(3): 341-363.

Mahoney, J. T., McGahan, A. M., \& Pitelis, C. N. 2009. The interdependence of private and public interests. Organization Science, 20(6): 1034-1052.

March, J. G. 1994. A primer of decision making: How decisions happen. New York: Free Press.

Marshall, M. 2012. Controversial geoengineering field test cancelled, NewScientist: URL: http://www.newscientist.com/article/dn21840-controversial-geoengineering-field-testcancelled.html. Site accessed April 24, 2013.

Martens, B. J., Crum, M. R., \& Poist, R. F. 2011. Examining antecedents to supply chain security effectiveness: An exploratory study. Journal of Business Logistics, 32(2): 153-166.

McCarter, M. W., Budescu, D. V., \& Scheffran, J. 2011. The give-or-take-some dilemma: An empirical investigation of a hybrid social dilemma. Organizational Behavior \& Human Decision Processes, 116(1): 83-95.

McCarter, M. W., Mahoney, J. T., Northcraft, G. B. 2011. Testing the waters: How collective real options manage the social dilemma of strategic alliances. Academy of Management Review, 36(4): 621-640.

McCarter, M. W., \& Northcraft, G. B. 2007. Happy together?: Insights and implications of viewing managed supply chains as a social dilemma. Journal of Operations Management, 25(2): 498-511.

McCorkle, D. E., Reardon, J., Alexander, J. F., Kling, N. D., Harris, R. C., \& Iyer, R. V. 1999. Undergraduate marketing students, group projects, and teamwork: The good, the bad, and the ugly? Journal of Marketing Education, 21(2): 106-117.

Mentzer, J. T., DeWitt, W., Keebler, J. S., Soonhoong, M., Nix, N. W., Smith, C. D., \& Zacharia, Z. G. 2001. Defining supply chain management. Journal of Business Logistics, 22(2): 125.

Messick, D. M. 1999. Alternative logics for decision making in social settings. Journal of Economic Behavior \& Organization, 39(1): 11-28.

Messick, D. M., \& Brewer, M. 1983. Solving social dilemmas. In L. Wheeler, \& Shaver, P. (Ed.), Review of personality and social psychology, Vol. 4: 11-44. Beverly Hills: Sage Publications.

Morgan, R. M., \& Hunt, S. D. 1994. The commitment-trust theory of relationship marketing. Journal of Marketing, 58(3): 20-38.

Muraskin, W. A. 1998. The politics of international health: The children's vaccine initiative and the struggle to develop vaccines for the third world. Albany, NY: State University of New York Press. 
Narrod, C., Roy, D., Okello, J., Avendaño, B., Rich, K., \& Thorat, A. 2009. Public-private partnerships and collective action in high value fruit and vegetable supply chains. Food Policy, 34(1): 8-15.

New York Thoroughbred Horseman's Association Newsletter. 2012. Ponying up for aftercare. http://www.nytha.com/pdf/nytha_spring_newsletter_2012.pdf. Site accessed April 24, 2013.

Nickerson, J. A., Hamilton, B. H., \& Wada, T. 2001. Market position, resource profile, and governance: Linking Porter and Williamson in the context of international courier and small package services in Japan. Strategic Management Journal, 22(3): 251-273.

Ogden, J. A., \& McCarter, M. W. 2004. Better buyer-supplier relationships and increased value through supply base reduction and supplier performance measurement. Practix, 8(December): 1-6.

Olson, M. 1965. The logic of collective action: Public goods and the theory of groups. Cambridge: Harvard University Press.

Ordóñez, L. D., Schweitzer, M. E., Galinsky, A. D., \& Bazerman, M. H. 2009. On good scholarship, goal setting, and scholars gone wild. Academy of Management Perspectives, 23(3): 82-87.

Ostrom, E. 1990. Governing the commons. New York: Cambridge University Press.

Ostrom, E. 1998. A behavioral approach to the rational choice thoery of collective action. American Political Science Review, 92(1): 1-22.

Reich, M. R. 2000. Public-private partnerships for public health. Nature Medicine, 6(6): 617620.

Rockmann, K. W., \& Northcraft, G. B. 2008. To be or not to be trusted: The influence of media richness on defection and deception. Organizational Behavior \& Human Decision Processes, 107(2): 106-122.

Rousseau, D. M., Sitkin, S. B., Burt, R. S., \& Camerer, C. 1998. Not so different after all: A cross-discipline view of trust. Academy of Management Review, 23(3): 393-404.

Ruben, R., Boselie, D., \& Lu, H. 2007. Vegetables procurement by Asian supermarkets: A transaction cost approach. Supply Chain Management: An International Journal, 12(1): 60-68.

Ruester, S., \& Neumann, A. 2009. Linking alternative theories of the firm-a first empirical application to the liquefied natural gas industry. Journal of Institutional Economics, 5(1): 47.

Salon. 2001. India's salt wars. http://www.salon.com/2001/08/20/salt/. Site accessed April 24, 2013. 
Sarkar, A. \& Mohapatra, P. 2006. Evaluation of supplier capability and performance: A method for supply base reduction. Journal of Purchasing \& Supply Management, 12(3): 148163.

Sato, K. 1988. Trust and group size in a social dilemma. Japanese Psychological Research, 30(2): 88-93.

Schoenherr, T., \& Swink, M. 2012. Revisiting the arcs of integration: Cross-validations and extensions. Journal of Operations Management, 30(1): 99-115.

Schwartz-Shea, P., \& Simmons, R. T. 1995. Social dilemmas and perceptions: Experiments on framing and inconsequentiality. In D. Schroeder (Ed.), Social dilemmas: Perspectives on individuals and groups: 87-103. Westport, CT: Praeger.

Schwartz, S. H. 1970. Elicitation of moral obligation and self-sacrificing behavior: An experimental study of volunteering to be a bone marrow donor. Journal of Personality \& Social Psychology, 15(4): 283-293.

Skelcher, C. 2005. Public-private partnerships and hybridity. In E. Ferlie, L. E. Lynn, \& C. Pollitt (Eds.), Oxford handbook of public management: 347-370. Oxford, UK: Oxford University Press.

Smith, R., Woodward, D., Acharya, A., Beaglehole, R., \& Drager, N. 2004. Communicable disease control: A 'global public good' perspective. Health Policy \& Planning, 19(5): 271-278.

Staw, B. M. 1991. Dressing up like an organization: When psychological theories can explain organizational action. Journal of Management, 17(4): 805-819.

Sun Times. 2012. Animal shelter taking care of horses dumped near Lowell. http://posttrib.suntimes.com/news/lake/13758567-418/animal-shelter-taking-care-ofhorses-dumped-near-lowell.html. Site accessed April 24, 2013.

Tenbrunsel, A. E., \& Northcraft, G. B. 2010. In the eye of the beholder: Payoff structures and decision frames in social dilemmas. In R. Kramer, A. E. Tenbrunsel, \& M. H. Bazerman (Eds.), Social decision making: Social dilemmas, social values, and ethical judgments: 95-115. New York, NY: Psychology Press.

Tikao, K., Higgins, N., Phillips, H., \& Cowan, C. 2009. Kāpo (blind) Māori in the ancient world. MAI Review, 2(1): 4-19.

UNICEF. 2010. Enhancing nutrition access through public-private partnerships. The role of nonstate providers in delivering basic social services for children, pp. 1-2. ADB.

Van de Ven, A. H., \& Ring, P. S. 2006. Relying on trust in cooperative inter-organizational relationships. In R. Bachmann \& A. Zaheer (Eds.), Handbook of trust research: 144164. Cheltenham, UK: Elgar. 
van Dijk, E., \& Wilke, H. 1997. Is it mine or is it ours? Framing property rights and decision making in social dilemmas. Organizational Behavior \& Human Decision Processes, 71(2): 195-209.

Van Lange, P. A. M., Joireman, J., Parks, C. D., \& Van Dijk, E. 2013. The psychology of social dilemmas: A review. Organizational Behavior \& Human Decision Processes, 120(2): 125-141.

Vangen, S., \& Huxham, C. 2003. Nurturing collaborative relations building trust in interorganizational collaboration. Journal of Applied Behavioral Science, 39(1): 5-31.

Weber, J. M., Kopelman, S., \& Messick, D. M. 2004. A conceptual review of decision making in social dilemmas: Applying a logic of appropriateness. Personality \& Social Psychology Review, 8(3): 281-307.

Weick, K. E. 1984. Small wins: Redefining the scale of social problems. American Psychologist, 39(1): 40-49.

Weihe, G. 2010. Towards a process perscpetive on public-private partnerships. In G. A. Hodge, C. Greve, \& A. E. Boardman (Eds.), International handbook on public-private partnerships: 510-525. Cheltenham, UK: Elgar.

Whiteley, R. 2010. Stud fees and profitability the real story, Thoroughbred Daily News, Vol. 105: $12-16$.

Yescombe, E. R. 2007. Public-private partnerships: Principles of policy and finance. Boston, MA: Butterworth-Heinemann.

Zaheer, A., \& Kamal Fudge, K. 2011. Creating trust in piranha-infested waters: The confluence of buyer, supplier and host country contexts. Journal of International Business Studies, 42(1): 48-55.

Zaheer, A., McEvily, B., \& Perrone, V. 1998. Does trust matter? Exploring the effects of interorganizational and interpersonal trust on performance. Organization Science, 9(2): 141159.

Zeng, M., \& Chen, X-P. 2003. Achieving cooperation in multiparty alliances: A social dilemma approach to partnership management. Academy of Management Review, 28(4): 587-605.

Zhu, Q., \& Sarkis, J. 2004. Relationships between operational practices and performance among early adopters of green supply chain management practices in Chinese manufacturing enterprises. Journal of Operations Management, 22(3): 265-289. 
Table 1. An integrative taxonomy of solutions to public-private partnership social dilemmas

\section{What does the solution affect?}

\begin{tabular}{|c|c|c|c|}
\hline \multirow{3}{*}{$\begin{array}{l}\text { How is the solution } \\
\text { implemented? }\end{array}$} & & $\begin{array}{c}\text { Structure } \\
\text { (Perceptions of payoffs) }\end{array}$ & $\begin{array}{l}\text { Motivations } \\
\text { (Perceptions of partners) }\end{array}$ \\
\hline & $\begin{array}{l}\text { Jointly } \\
\text { (Integrated) }\end{array}$ & \begin{tabular}{ll}
\multicolumn{1}{c}{ I } \\
- & Criticality \\
- & Number of partners
\end{tabular} & \begin{tabular}{ll} 
& \multicolumn{1}{c}{ II } \\
- & Perceived interdependence \\
- & Beneficiary contact
\end{tabular} \\
\hline & $\begin{array}{l}\text { Unilaterally } \\
\text { (Autonomous) }\end{array}$ & \begin{tabular}{ll} 
& \multicolumn{1}{c}{ III } \\
- & Informal sanctions \\
- & Framing ownership
\end{tabular} & $\begin{array}{ll}\text { IV } \\
\text { - } & \text { Communication } \\
\text { - } & \text { Group identity }\end{array}$ \\
\hline
\end{tabular}

